\title{
Merger and Acquisition in the Banking Sector
}

\section{Summary}

The article presents situation on mergers and acquisitions $(M \& A)$ in banking sector during last twenty years. The main motives are selected and analyzed. All is explained on the base on research reports of the Deutsche Bundesbank and the European Central Bank.

\section{Introduction}

The recent flurry of big mergers is attracting much attention, partly because of heightened interest in what motivates firms to merge and how mergers affect competition and the economy.

A large process of financial consolidation has taken place in the European Union in the last years, although cross-border mergers and acquisitions activity remains limited in the banking sector. Given the central role played by banks in the credit process and the economy in general, this process of financial consolidation has attracted substantial attention not only from managers and shareholders but also from borrowers and policymakers (Masseli, 2005).

One often-held view of mergers is that firms are merging just to get bigger. Accompanying that notion is a fear that as merging firms grab greater market share, individual redeems and competition are threatened, because bigger is perceived as greater concentration of power. But it is far more than only the desire to become bigger. Mergers enable the banking industry to take advantage of new opportunities created by changes in the technological and regulatory environment. While mergers have certainly reduced the number of banks nationwide, concentration of power in local banking markets has not increased (Hackethal, 2007: 387-424).

\footnotetext{
* Mgr, Vienna University of Economics and Business Administration, Austria.
} 


\section{The German Banks}

German banks experienced a merger wave throughout the last 20 years. However, the success of bank mergers remains a continuous matter of debate. The drastic and continuous decline of the number of competitors since the early 1990s is one of the lighthouse cases put forward as an illustration of this claim. In fact, the number of banks constituting the three pillars ${ }^{1}$ of German banking declined from 4177 to 1920 due to mergers and acquisitions between 1991 and 2007 (Koetter, Bos, Heid, Kolari, Kool, Porath, 2007: 1-33). Mergers are categorised as a success that fulfil simultaneously two criteria. First, merged institutes must exhibit cost efficiency (CE) levels above the average of non-merging banks. Second, banks must exhibit cost efficiency changes between merger and evaluation year above efficiency changes of non-merging banks. This taxonomy is employed to characterise (successful) mergers in terms of various keyperformance and structural indicators and investigate the implications for three important policy issues. The main conclusions are (Masseli, 2005):

- approximately every second merger is a success,

- the margin of success is narrow, as the CE differential between merging and nonmerging banks is one percentage point.

Since the early 1990s the number of banks declined substantially in most financial systems. Ongoing consolidation is a global phenomenon. However, it has been most remarkable in the largest banking market in Europe in Germany. According to the most recent report on EU banking structures by the European Central Bank (ECB) the number of credit institutions in Germany declined by approximately 45 percent between 1997 and 2007, by far the largest reduction in the EU (Koetter, Bos, Heid, Kolari, Kool, Porath, 2007: 1-33). Yet, Germany still hosts most banks in Europe and exhibits the most fragmented market in this comparison. This may explain why for example the ECB expects further bank mergers especially among relatively small savings and cooperative banks. An evaluation of the success of past merger activity is therefore crucial. A stochastic cost frontier is estimate to measure the Cost Efficiency (CE) of banks.

On the basis of a comparison of both efficiency levels and changes of merging versus non-merging banks it is distinguished successful from non-successful mergers. Only those banks that exhibit simultaneously higher levels and changes in efficiency after a transaction are deemed a success. The main result is that approximately every second merger is a success according to this taxonomy. However, the mean difference between merging and non-merging banks is slim. On average, CE levels of the former are around a mere percentage point higher compared to the according cohort of non-merging banks in a given year.

This difference remains fairly stable for a range of one to nine years that elapsed after a deal. This grouping is used to investigate if mergers that are subject to three deal specific characteristics are more or less often a success or a failure. The first deal specific characteristic is the size of pre-merger CE differentials between targets and acquirers to capture the potential for learning benefits due to the transfer of managerial skills.

${ }^{1}$ The three pillars are commercial, savings and cooperative banks. 
It is indicated that only in the short run larger differentials lead more often to efficiency gains. In the long run, the partners succeed more frequently in terms of CE. The second deal-specific characteristic refers to the usefulness of mergers as a tool to resolve bank distress. Banks emerging from a deal that involved a distressed target are approximately as often in the success group as non-distressed mergers. However, those deals where the acquiring institute is distressed exhibit less frequently CE levels and changes above the benchmark set by non-merging banks (Beitel, Schiereck, Wahrenburg, 2006: 1-40).

\section{Competitive Pressure}

The study of the Deutsche Bundesbank (2007) has on its disposal data on all savings and cooperative banks for the period from 1993 until 2007. The focus is put on two pillars for three reasons:

- they account for more than a third of total assets managed in the German banking system and represent more than 80 percent of all banks in terms of number,

- the vast majority of mergers occurred among these institutes. While a number of studies focus on mergers among publicly listed banks, this study provides the only evidence on the (lack of) success of mergers for these banking sectors as a whole,

- Hackethal (2007: 387-424) points out that savings and cooperative banks are vital to the backbone of Germany's economy, namely the "Mittelstand".

All banks operating in Germany annually report balance sheet and profit and loss account data. To grasp the dynamics of competitive pressure during the last decade, the following table hast to be considered. Profitability as measured by Return on Equity (ROE) more than halved in this period. If competition increases, prices are driven down to marginal cost. As markets approach perfect competition, textbook economic theory predicts that no additional rents above marginal cost can be realised. Marginal cost cannot be observed. But the development of ROE indicates in any case that comfortable profit bolsters during the early 1990s no longer prevail among German banks.

The fact that Cost-Income Ratios (CI) stayed fairly constant in the course of events signals that the deterioration of profitability cannot be explained by poor bank management alone. In such a case, administrative expenses as a share of operating revenue should have soared in lock-step. However, with the exception of the period involving stock market crashes around the turn of the century, we observe that mean $\mathrm{CI}^{2}$ ratios seem to have been kept in check on an ongoing basis. At the same time, deteriorating net Interest Margins (NIM) could reflect how spreads between lending and borrowing are competed away. Seemingly, ongoing consolidation, as illustrated by the declining number of banks, did not result in banks seeking monopoly rents. Individual cooperative and savings banks might still be too small to exercise market power. The mean size of banks increased from around $\mathrm{C}=300 \mathrm{~m}$ to a still fairly small scale of operations of $\mathrm{C}=820 \mathrm{~m}$. This indicates that despite increasing mean size banks continued to face considerable competition.

${ }^{2} \mathrm{CI}=$ Cost-Income Ratios. 
Wspótczesna EKonOMIa

Table 1. Key performance indicators of German banking 1993-2003

\begin{tabular}{|c|c|c|c|c|c|}
\hline Year & ROE ${ }^{1)}$ & $\mathrm{Cl}^{2)}$ & $N^{\prime} M^{3)}$ & $\mathrm{HHI}^{4)}$ & Banks \\
\hline 1993 & 19.5 & 70.6 & 3.2 & 2,976 & 3,464 \\
\hline 1994 & 15.7 & 67.1 & 3.3 & 3,080 & 3,305 \\
\hline 1995 & 18.3 & 69.6 & 3.1 & 3,142 & 3,203 \\
\hline 1996 & 16.5 & 70.2 & 3.1 & 3,199 & 3,103 \\
\hline 1997 & 14.5 & 70.5 & 3.0 & 3,263 & 3,004 \\
\hline 1998 & 12.2 & 72.6 & 2.7 & 3,350 & 2,833 \\
\hline 1999 & 10.9 & 73.6 & 2.7 & 3,514 & 2,597 \\
\hline 2000 & 9.3 & 74.2 & 2.7 & 3,656 & 2,347 \\
\hline 2001 & 7.3 & 75.8 & 2.6 & 3,788 & 2,147 \\
\hline 2002 & 7.9 & 72.8 & 2.7 & 3,967 & 1,999 \\
\hline 2003 & 9.3 & 71.6 & 2.8 & 4,110 & 1,868 \\
\hline Total & 13.6 & 71.4 & 2.9 & 3,389 & 29,870 \\
\hline
\end{tabular}

1) Ewturn on equity;

2) Cost-income ratio;

3) Net interect margin;

4) Hirschman-Herfindahl Index between 1 and 10,000 per county.

Source: Deutsche Bundesbank, Bank Studies, Mergers and Regulation, Frankfurt am Main 2007.

Consequently, excessive market power is at first sight a minor concern. Not a single bank exited the market due to outright failure during the observation period. The consolidation nonetheless left a profound imprint on Germany's banking structure. Local market concentration increased by more than 25 percent $^{3}$. Measured by total assets under management per county and year we record an increase in the Hirschman-Herfindahl Index from just below 3000 to 4110 points between 1993 and 2003.

In sum, simple Key Performance Indicators (KPI) convey in line with Bikker and Bos (2005: 9-80) that competitive pressures increased among German banks during the last decade despite increasing concentration. A massively reduced number of institutes bear witness to a changing bank market structure. The brunt of these changes is in fact borne by mergers. The massive reduction of the number of banks demands an evaluation of the success of mergers and the implications for the industry in a more detailed fashion.

\section{Consolidation}

The Deutsche Bundesbank collected data on 1417 targets during the period from 1994 to $2002^{4}$. The table provides data on the mean size of acquiring, target and non-

\footnotetext{
${ }^{3}$ Note, that we do not attempt here a formal investigation of the causal relation between market power, concentration and prices. We rather restrict ourselves to simply acknowledge that market structure changed substantially in terms of markedly fewer banks managing increasingly larger volumes of assets.

${ }^{4}$ The total number of targets is 1465 in the reference period, representing a decline from 3464 institutes in 1993 to 1999 institutes in 2002. We had to discard 48 mergers due to missing data on either the acquirer or the target. We lack information prior to 1994 and after 2002.
} 
Table 2. Size and number of mergers per sector

\begin{tabular}{|c|c|c|c|c|c|c|c|}
\hline \multicolumn{8}{|c|}{ Savinks Banks } \\
\hline Merger year & Acquirer1) & Targeta $^{1)}$ & Non-merging ${ }^{1)}$ & Total TA ${ }^{2)}$ & & N Acquirer3) & N Target \\
\hline 1994 & 0,770 & 295 & 1,166 & 13,900 & & 36 & 47 \\
\hline 1995 & 0,504 & 317 & 1,253 & 9,200 & & 22 & 29 \\
\hline 1996 & 1,630 & 384 & 1,329 & 6,530 & & 13 & 17 \\
\hline 1997 & 1,660 & 764 & 1,411 & 6,120 & & 7 & 8 \\
\hline 1998 & 1,890 & 683 & 1,493 & 2,730 & & 4 & 4 \\
\hline 1999 & 1,320 & 576 & 1,585 & 8,640 & & 12 & 15 \\
\hline 2000 & 1,560 & 863 & 1,605 & 12,900 & & 13 & 15 \\
\hline 2001 & 2,090 & 743 & 1,651 & 17,800 & & 20 & 24 \\
\hline 2002 & 3,810 & 567 & 1,705 & 9,630 & & 16 & 17 \\
\hline Mean & 1,520 & 497 & 1,523 & 11,400 & Sum & 143 & 176 \\
\hline \multicolumn{8}{|c|}{ Cooperative banks } \\
\hline 1994 & 180 & 53 & 160 & 5,700 & & 104 & 108 \\
\hline 1995 & 209 & 65 & 173 & 4,380 & & 65 & 67 \\
\hline 1996 & 321 & 68 & 187 & 5,290 & & 72 & 78 \\
\hline 1997 & 382 & 79 & 200 & 6,590 & & 79 & 84 \\
\hline 1998 & 355 & 95 & 211 & 15,100 & & 141 & 159 \\
\hline 1999 & 427 & 134 & 224 & 28,000 & & 174 & 209 \\
\hline 2000 & 394 & 112 & 234 & 26,700 & & 202 & 238 \\
\hline 2001 & 384 & 115 & 239 & 19,400 & & 147 & 169 \\
\hline 2002 & 455 & 155 & 252 & 20,000 & & 114 & 129 \\
\hline Mean & 362 & 106 & 220 & 18,000 & Sum & 1,098 & 1,241 \\
\hline
\end{tabular}

1) Mean total assets in mn Euro one year prior to transaction;

2) Sum of acquired assets in mn Euro;

3) Multiple acquirers only included once per year; serial acquirers included in each merger year.

Source: Deutsche Bundesbank, Bank Studies, Mergers and Regulation, Frankfurt am Main 2007.

merging banks in the year prior to the merger. These measures are depicted by banking group. Additionally, both the total volume and the number of acquirer and targets are supplied.

In accordance with Beitel, Schiereck and Wahrenburg (2007: 1-40), it can be observed that most mergers occurred among cooperative banks. While the number of German savings banks declined by approximately 20 percent from 654 banks in 1994 to 519 banks at year end of 2003, the corresponding decline of cooperative banks is 45 percent, reflecting a reduction in the number of banks from 2651 to 1480 in the same period $^{5}$. Consequently, the merger process in the two sectors might differ. For example, regulation and/or government ownership potentially shelters savings banks to a larger extent from competition compared to cooperatives. It can be expected that market structure and profitability measures are to exhibit these differences.

${ }^{5}$ Deutsche Bundesbank, Bank Studies, Mergers and Regulation, Frankfurt am Main 2007. 


\section{Characteristics}

If it is assumed that increased competition is indeed a major driving force of mergers and therefore changing market structures, it is interesting to learn about the immediate implications for bank's post-merger profitability and costs. The next table shows the mean key performance indicators (KPI) which is depicted to compare merging and non-merging banks across bank sectors in the year a deal occurred ${ }^{6}$.

Table 3. Mean characteristics of merging versus non-merging banks

\begin{tabular}{|l|c|c|c|c|c|c|}
\hline \multirow{2}{*}{ KPI } & \multicolumn{3}{|c|}{ Savings banks } & \multicolumn{3}{c|}{ Cooperative banks } \\
\cline { 2 - 7 } & Non & Merger & p-value & Non & Merger & p-value $^{6)}$ \\
\hline ROE & 15.6 & 8.4 & 0.000 & 13.7 & 8.7 & 0.000 \\
\hline $\mathrm{CI}$ & 65.6 & 70.4 & 0.000 & 71.8 & 75.9 & 0.108 \\
\hline $\mathrm{NIM}^{1)}$ & 2.7 & 2.8 & 0.213 & 2.9 & 2.8 & 0.000 \\
\hline $\mathrm{HH}^{2)}$ & 3,685 & 5,305 & 0.000 & 3,239 & 3,589 & 0.000 \\
\hline Prod $^{3)}$ & 0.29 & 0.33 & 0.000 & 0.33 & 0.34 & 0.000 \\
\hline $\mathrm{UC}^{4)}$ & 5.8 & 5.7 & 0.755 & 6.0 & 6.1 & 0.001 \\
\hline $\mathrm{INC}^{5)}$ & 7.7 & 7.7 & 0.941 & 8.8 & 10.4 & 0.000 \\
\hline $\mathrm{N}$ & 4,294 & 143 & & 8,508 & 1,098 & \\
\hline
\end{tabular}

1) Net interest margin in percent;

2) Hirschman-Herfindahl Index in points;

3) Productivity approximated as FTE per mn Euro of total assets;

4) Unit cost in cents of total operating cost per Euro of total assets;

5) Income structure as fee over total revenue in percent;

6) Test for equality of means.

Note: Excluding per-merger observations of ultimately merging banks.

Source: Deutsche Bundesbank, Bank Studies, Mergers and Regulation, Frankfurt am Main 2007.

Profitability differed significantly for both banking groups between merging and nonmerging banks by 5 to 7 percentage points of ROE. Likewise, cost pressure is higher for banks that just merged, as measured by higher CI ratios. However, comparably poor KPI (Key Performance Indicator) may result from a recent transaction, for example, due to the integration of a new sales force or from incurring additional advisor fees during the transaction. Local concentration, measured by HHI (Hirschman-Herfindahl Index), is higher among those banks that merged, especially for savings banks. Those banks that merged are thus operating in local markets with at times markedly fewer competitors. This can imply market power. But at the same time mean NIM (Net Interest Margin) do not differ a lot between merging and non-merging banks. Furthermore, for savings banks mean NIM is not significantly different despite substantially higher concentration among merging savings banks. Rent seeking therefore seems to be an issue of less importance in our sample. But while only limited evidence for rent seeking is found, higher concentration may still imply that market discipline is lacking and therefore banks fail to

${ }^{6}$ This is in contrast to table 2, where mean KPIs refer to pre-merger years. 
monitor costs carefully. Foregone cost savings imply unnecessary reductions of producer surplus and are thus undesirable. This line of thought is supported by higher CI ratios for merging banks of both sectors, when paired with higher mean concentration ${ }^{7}$.

In line with Koetter (2007), the described characteristics indicate that merging banks perform at best mediocre. But with regard to the evaluation of the success of mergers, it can be argued that all of the discussed measures suffer from two major limitations. The first caveat refers to the development of KPI over time. For example, lower labour productivity in the transaction year itself may merely reflect the rigidity of German labour laws. Adjustments of the labour force are time-consuming as, for example, numerous employees at savings banks are protected by civil servant status. Hence, large scale labour force reduction is only possible by using natural fluctuation rather than Anglo-Saxon style lay-off waves. Therefore, it is crucial to track the performance of merged institutes over some time. The second caveat is that any of the measures provide little information about what the optimal KPI could have been for banks operating under potentially markedly different circumstances. After all, the share of the difference between mean ROE for merging and non-merging banks that is attributable to poor management of the bank versus deteriorating economic conditions or sheer bad luck remains unclear.

It simply cannot be stated by observing some increased post merger ROE whether the firm performed optimally - a higher return after the merger might still be far from what could have been attained. An alternative strand in the literature therefore suggests benchmarking banks according to their ability to convert inputs into outputs ${ }^{8}$. Cost efficiency (CE) is employed to measure the success of mergers. This approach ranks firms relative to an optimal industry cost function. The appeal of this measure is to evaluate mergers on the basis of simple textbook microeconomic theory. It is to be assumed that banks operate on markets that are appropriately described by perfect competition ${ }^{9}$. Cost minimising firm is expected to produce its outputs by demanding required inputs subject to prevailing input prices. Estimating an optimal cost function under the assumption that deviations from best practice are, first, due to random noise and, second, due to inefficient allocation of inputs. Intuitively, no bank can incur systematically higher costs compared to competitors. To avoid being driven out of the market any bank has to demand inputs in optimal proportions to produce a given output vector. This also holds for banks which potentially pursue alternative objectives - in the long run no firm can afford systematically higher costs for identical production factors employed ${ }^{10}$.

${ }^{7}$ Note that the high p-value for the difference in mean test for cooperative banks may be due to outliers in the data. As we intend in this section to describe the stylized facts we included all banks which submitted data to the Bundesbank and were thus in operation. When estimating the efficient cost frontier we conducted robustness checks by excluding extreme observations. Results remained qualitatively unaffected

${ }^{8}$ See for example: Vannder Vennet (1996, 2003), DeYoung (1997) and Peristiani (1997).

${ }^{9}$ For the validity of this assumption see also: Bikker and Bos.

${ }^{10}$ In contrast, it may very well be possible that German savings and cooperative banks may not strictly maximise their revenues as to maximise profits. Therefore, ROE and other traditional performance measures may fall short to assess the success of bank mergers. But even with these philanthropic coobjectives it is plausible that while revenues may not be maximised any bank has to optimise its costs when allocating resources to provide financial services. 


\section{Facilitators and Obstacles to Merger and Acquisition Success}

It must be distinguished between successful and unsuccessful mergers. Of special interest is the development of bank-specific characteristics as measured by the previously introduced KPI over time. As opposed to these bank-specific characteristics, merger success might crucially depend on characteristics related to both how the deal is conducted and the environment in which it takes place. It is referred to these as deal-specific characteristics $^{11}$ :

1. Transfer of skills between merging banks.

2. Mergers as distress resolution tool.

3. Influence of regional demarcation.

With the exception of the influence of regional demarcation on merger success, these deal characteristics are regarded as endogenous to merger management. Regulation cannot be influenced by the management in charge of conducting the merger. Rather, investigation of the relation between regional demarcation and merger success intends to shed light on the costs and benefits of this arrangement.

\section{Transfer of Skills}

Lang and Welzel (2007: 63-84) investigate merger effects for a sample restricted to cooperative banks in the state of Bavaria. They find that in 53\% of all mergers the acquirer is more cost efficient than the target. However, only $18 \%$ of all merged banks with higher ex ante acquirer CE managed to exhibit above average efficiency growth after the merger. In contrast, they find that $35 \%$ of all mergers with positive ex ante $\mathrm{CE}$ differences yield below average $\mathrm{CE}$ growth after the merger. They conclude that these acquirers failed to transfer their superior CE skills to the target. This finding reflects that the transfer of cost management skills matters a lot to determine success but that it can be difficult to accomplish. If banks with superior CE performance manage to lift the merged units' overall CE, mergers are a desirable because they improve the competitive position of a bank and thereby strengthen the stability of the whole banking system ${ }^{12}$.

Whether a beneficial transfer of skill is successful depends on two major factors. First, the size of the ex ante differential. On the one hand, a larger differential can indicate that cost management skills of one of the partners are clearly below those of the other partner. Then, potential for improvement is easily identified. Relatively large gains may be quickly realised by simple imitation. An example is that one bank pursues excessive spending on real estate resulting in excessive office capacities. Switching to facilities closer to market cost then entails a quick win if switching costs are low enough. On the

${ }^{11}$ Clearly, there is a virtually infinite number of additional factors that may matter, for example board compositions or local macroeconomic environments. Our choice here is motivated by the availability of data and the policy relevance of the deal characteristic from our point of view.

${ }^{12}$ How far such joint CE must be lifted depends on the definition of a successful merger. We discuss that matter at length in the next subsection. 
other hand, a large differential can indicate that one partner suffers from substantial problems that cannot be easily remedied. An example is a funding structure incurring too high interest payments. If these are stipulated in contracts there is presumably little a new management team can do in the short run.

The second factor refers to whether it is the target or the acquirer that exhibits higher $\mathrm{CE}$. Acquirers that are dominant in terms of CE may very well command sufficient power to enforce their management procedures on the target.

Consequently, majority stakes cannot be accumulated in a hostile fashion. The absence of a full-fledged market for corporate control may imply that objectives other than value maximisation are important for determining the acquirer and target in a merger. If it is indeed to some extent a political process that determines the role in a merger, it may turn out that a large but potentially less efficient bank is the acquirer. Then, it can be less likely that best practise from the target is wholeheartedly embraced by the new organisation. Whether such scenarios prevail and whether we can observe particular combinations of pre-merger CE differentials to yield systematically more (or less) successful mergers remains an empirical question that we address below. This way, bankers, head organisations and regulators can evaluate pending mergers on the basis of pre-merger CE differentials to promote beneficial combinations that are likely to improve CE.

\section{Mergers and Distress}

As no single bank went into outright bankruptcy it is reasonable to expect that a number of bank mergers served the purpose to remedy distress. The next table underpins that around 100 mergers are identified as distressed transactions. The literature from Porath (2004: 1-32) and Koetter et al. (2007: 1-33) are retrieve data on distressed banks from the Bundesbank's database on default information. The only focus here is put on

Table 4. Distressed merger partners

\begin{tabular}{|c|c|c|c|c|c|}
\hline Year & None & Target & Acquirer & Both & Total \\
\hline 1994 & 155 & n.a. & n.a. & n.a. & 155 \\
\hline 1995 & 91 & 1 & 4 & 0 & 96 \\
\hline 1996 & 90 & 2 & 3 & 0 & 95 \\
\hline 1997 & 85 & 2 & 3 & 2 & 92 \\
\hline 1998 & 141 & 12 & 10 & 0 & 163 \\
\hline 1999 & 199 & 14 & 9 & 2 & 224 \\
\hline 2000 & 233 & 12 & 7 & 1 & 193 \\
\hline 2001 & 176 & 4 & 12 & 1 & 193 \\
\hline 2002 & 146 & n.a. & n.a. & n.a. & 146 \\
\hline Total & 1,316 & 47 & 48 & 6 & 1,417 \\
\hline
\end{tabular}

Note: Savings and cooperative banks.

Source: Deutsche Bundesbank, Bank Studies, Mergers and Regulation, Frankfurt am Main 2007. 
those events that represent restructuring efforts by means of mergers ${ }^{13}$. As can be seen in the following table, distressed mergers are not limited to cases where a bank becomes a target.

In fact, it occurred equally often that distress resulted in the bank acquiring a nondistressed bank. Only in six cases, both parties involved in the merger were classified as distressed by Bundesbank records.

\section{Mergers and regional proximity}

The process of merging involves additional important institutions next to the Bundesbank and the Federal Institute for Financial Services Supervision ("Bundesanstalt für Finanzdienstleistungsaufsicht, BaFin"). These are the respective head organisations of the savings and cooperative bank sectors, DSGV and BVR, respectively. While supervision authorities adhere to principles of financial soundness and stability, representatives of these head organisations guard what is known as the principle of regional demarcation ("Regionalprinzip")14. This principle is de facto enforced among both cooperative and savings banks. It stipulates that regional banks of these sectors must not conduct operations beyond the borders of their assigned region. The objective of this regulation is to ensure that rural and economically weak areas are also supplied with financial services in Germany. Consequently, many mergers among savings and cooperatives involve banks which are geographically close to each other. The following table depicts the number of mergers where both target and acquirer originate from the same region. In 64 percent of the events, mergers among savings banks involve targets and acquirers that originated from the same county ("Kreis") ${ }^{15}$. Approximately 15 percent of all mergers in this group concern banks from the same municipality ("Gemeinde") ${ }^{16}$.

For cooperative banks regional proximity of merger partners is even more evident. In almost 80 percent of all the cases, both parties are from the same county. A quarter of all cooperative bank mergers involve banks from the same municipality. There are two main reasons why mergers in the same region can be superior. First, it is possible that these transactions serve the purpose of reaching some required minimum size to operate efficiently. If two banks serve the same community with considerable overlap in their customer base, joined operations can help reduce unit costs if excess capacities, for example branches or employees, are reduced.

\footnotetext{
13 Detailed definitions of distress can be found in Porath (2004) and Koetter et al. (2005).

${ }^{14}$ Legal definitions of financial soundness and stability, to which both Bundesbank and BaFin adhere, are outlined in a series of laws. The German Banking Act ("Kreditwesengesetz, KWG") is the most important one and is complemented by a number of regulations.

${ }^{15}$ Equal to the sum of county and municipality mergers over total, i.e. $(86+26): 176$, as one county is distinguished into multiple municipalities.

16 Ideally, we investigate the geographical distance between target(s) and acquirer given the prevailing regional demarcation issued by the head organisations. Alas, this information is not available and we have to resort to publicly available regional indicators of counties and municipalities where banks are located. The number of counties with banks is 438 and the according number of municipalities is 2333.
} 
Table 5. Regional origin of merging banks

\begin{tabular}{|c|c|c|c|c|c|c|}
\hline Region & \multicolumn{2}{|c|}{ County } & \multicolumn{2}{c|}{ Minicipality } & \multicolumn{2}{c|}{ Total } \\
\hline Year & Savings & Coop's & Savings & Coop's & Savings & Coop's \\
\hline 1994 & 28 & 60 & 3 & 29 & 47 & 108 \\
\hline 1995 & 15 & 34 & 7 & 19 & 29 & 67 \\
\hline 1996 & 6 & 35 & 4 & 30 & 17 & 78 \\
\hline 1997 & 4 & 44 & 2 & 25 & 8 & 84 \\
\hline 1998 & 1 & 91 & 1 & 41 & 4 & 159 \\
\hline 1999 & 5 & 129 & 1 & 36 & 15 & 209 \\
\hline 2000 & 6 & 136 & 4 & 50 & 15 & 238 \\
\hline 2001 & 13 & 88 & 3 & 36 & 24 & 169 \\
\hline 2002 & 8 & 77 & 1 & 22 & 17 & 129 \\
\hline Total & 86 & 694 & 26 & 288 & 176 & 1,241 \\
\hline
\end{tabular}

Source: Deutsche Bundesbank, Bank Studies, Mergers and Regulation, Frankfurt am Main 2007.

Second, mergers among banks from the same vicinity may be superior because the acquirer is presumably familiar with local market conditions, for example weaknesses and strengths of local corporate firms, local politics or customer habits.

On the other hand, it is possible that the Regionalprinzip implies a lack of potential partners in a given region. Then it is more likely that target and acquirer may fail to complement each other, e.g. in terms of product range or funding structure. Mergers of banks located fairly close to each other might merely reflect restrictions imposed by regulation. Another reason why close regional proximity can result in inferior post merger performance is a lack of regional (income) diversification. The merged institute's revenue basis will be further concentrated within confined boundaries, thus exposing the bank to a larger degree to local macroeconomic conditions ${ }^{17}$.

\section{Successful Mergers}

Identification of successful mergers on the basis of the level of efficiency alone might be misleading. Consider as an example a bank that merged in 1995. Assume it exhibits $\mathrm{CE}$ of 80 percent in 1997 relative to an average CE of non-merging banks of 75 percent. On this basis alone the merger may then be considered a success. But if the bank exhibited cost efficiency of 85 percent in the year of the merger, 1995, the decline by 5 percent is hardly an achievement. Therefore mergers are compared along two dimensions.

The first dimension is the acquirer's change in $\mathrm{CE}$ in year $\mathrm{t}$ relative to the year of the merger. The second is the level of $\mathrm{CE}$ of the merged institute in year $\mathrm{t}$ after the merger.

${ }^{17}$ Note an important caveat. Regions assigned to banks are not publicly available. Therefore, we have to resort here to available regional identifiers, namely counties and municipalities. Hence, our approach to investigate the relation between regional proximity and successful mergers should be understand as a crude approximation of the implications of the principle of regional demarcation only. 
Graph 1. Performance of 1995 mergers two years after transaction

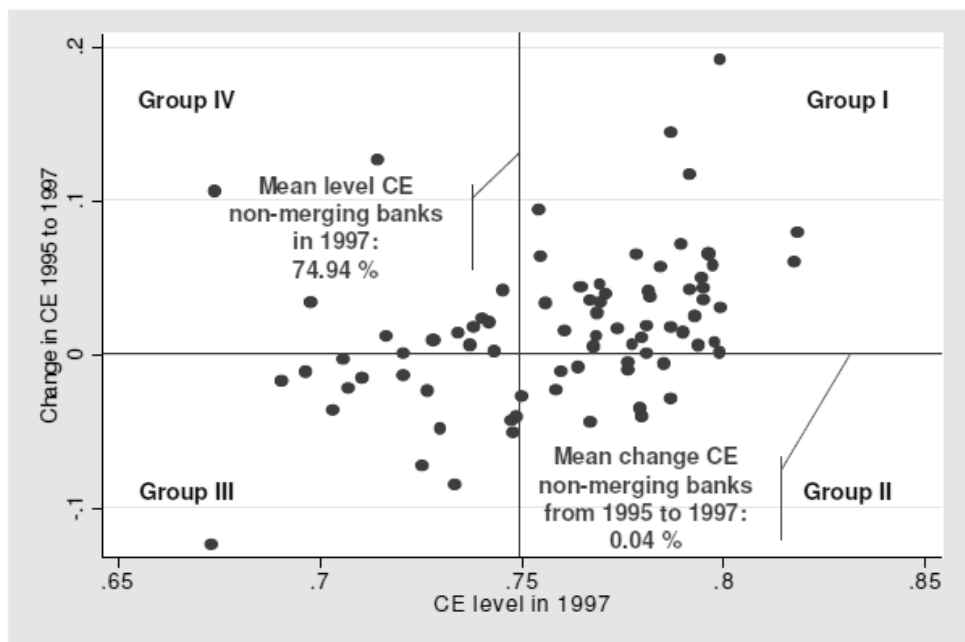

The first dimension captures changes in CE. As many practitioners point out, potential gains require some time until they materialise. Therefore, efficiency reports changes for a range of time $t$ from 1 until $9^{18}$. To evaluate whether a particular merger was successful, a benchmark is used as the average efficiency change of those banks that never merged, i.e. mean $\mathrm{CE}$ of all banks like $\mathrm{D}$ in figure 1 in year $\mathrm{t}^{19}$. Hence, a decline in efficiency need not necessarily imply a bad merger. If a bank suffered, for example, from a five percent drop in $\mathrm{CE}$ but the group of non-merging banks experienced a drop of ten percent, the merger helped to offset the negative trend. For example, when comparing the two-year $\mathrm{CE}$ change of a bank that merged in 1995 in 1997 with the CE change of non-merging banks in the same two years.

The second dimension is the level of CE of merging and non-merging banks. For example, along this second dimension, we compare a bank that merged in 1995 two years after the merger relative to the level of mean CE of non-merging banks in $1997^{20}$. Consider

${ }^{18}$ We have information about merger activities between 1994 and 2002. Hence, the maximum number of post-merger years available is nine years, namely from 1995 to 2003.

${ }^{19}$ We refer henceforth to those banks that never merged as non-merging banks. Thereby, we avoid comparing in a given year merging bank's performance to a benchmark that includes some banks which may merge later on. In fact, a banks' $\mathrm{CE}$ one year prior to merger may already differ markedly from $\mathrm{CE}$ of banks never merging and can thus constitute a poor benchmark sample. By excluding bank-year observations of institutes that eventually merge we avoid furthermore a potential upward bias in the benchmark if successful banks merge early. Including these successful early movers in the merger wave would then constitute a too high benchmark for those relatively poor performing banks that follow suit at later stages of the merger wave.

${ }^{20}$ Note that our formulation of a benchmark is quite conservative as it requires successful mergers to outperform non-merging banks simultaneously along two dimensions. Alternative and less rigorous benchmarks are conceivable. For example, Vander Vennet (2003) compares on the one hand pre- and 
as an example figure 2. Mergers are defined in the north-eastern quadrant, group I, as a success. These transactions yield, first, higher CE levels compared to non-merging banks in the year examined and, second, enjoyed an increase in CE since the merger above the mean $\mathrm{CE}$ change of non-merging banks during the same time period. Below, if these successful mergers are examined also exhibit other favourable KPI, e.g. higher profitability and lower CI ratios. Likewise, we examine if successful (as well as unsuccessful) mergers exhibit a clear profile in terms of deal-specific characteristics in terms of transferring skills, regional proximity of partners, distress and learning effects.

The south-eastern quadrant, group II, is deemed unsuccessful. Merged banks exhibit above non-merging average $\mathrm{CE}$ two years after the transaction. But the change in $\mathrm{CE}$ is lower compared to the mean change of non-merging banks. Such mergers are unsuccessful because, for the example of an increasing industry trend in $\mathrm{CE}$, the bank failed to match positive market developments. This could be the case if the acquiring bank was already highly cost efficient prior to the merger leading to high levels of CE in the merger year itself $^{21}$. A high level of $\mathrm{CE}$ could have led to a too relaxed attitude towards rolling out superior cost management skills at the target quickly. It is expected to obtain an indication if banks with extreme pre-merger differentials fall relatively more often into this (or other) merger groups, reflecting either inability or sheer neglect of transferring knowledge.

The south-western quadrant, group III, depicts the worst mergers. In the above example, mergers conducted in 1995 resulted two years later in CE levels below those of non-merging banks in 1997, i.e. 74,94\%. Moreover, these banks exhibit a change in CE below the average of non-merging banks, namely 0.04 percent. It is seen that these banks do also perform poorly in terms of traditional KPI as they exhibit in terms of CE neither high levels of cost management skill nor above average improvements. Finally, the northwestern quadrant, group IV, depicts banks with below non-merging banks' mean CE but with above average changes in CE. Consequently, these transactions are not univocally a success. But they may have the largest potential as promising changes in CE may indicate above average efficiency after some more time. It is interesting below if, for example, especially those mergers are a success where one partner suffered from clear deficiencies as reflected by distress. While turning around a distressed bank could imply below average levels of $\mathrm{CE}$ for a while, focused restructuring efforts could show up in our taxonomy as above average improvements of CE. Before turning to an assessment of the German merger wave on the basis of our results let briefly point out a potential caveat. The two dimensions on which our grouping is based, namely the level and change of CE, respectively, are not entirely independent from each other. A bank that exhibits above

post-merger efficiency rankings within the group of merging banks and on the other he compares these measures between merging banks and those of a peer group selected on the basis of institutional form, country and size. Here, we prefer to explicitly allow the merger event to enter the fixed effect of the frontier and thereby influence the relative benchmark more directly. Regarding the alternative of a peer group comparison we acknowledge here that our sample already is much more homogenous compared to a cross-country study. Given the large number of mergers we argue that the choice of relevant peer groups would be hard to achieve and is likely to result in arbitrary selection criteria.

${ }^{21}$ Note, however, that we do not consider here how efficient the bank was in the year of the merger but compare it to the benchmark t years after the merger. 
average CE changes after up to nine years after the merger is also more likely to end up with a level of CE above the average CE of non-merging banks. However, we argue that most alternative approaches that rely either on level of CE or, for that matter, other KPI do suffer from even more severe problems as these approaches neglect the development of the chosen performance ratio entirely.

\section{Conclusion}

Taxonomy is suggested as how to evaluate the merger wave of German savings and cooperative banks. Cost efficiency (CE) estimates are employed to obtain with stochastic frontier analysis to benchmark banks on the basis of their ability to efficiently convert inputs into outputs.

Successful mergers are defined as those which, first, yield CE levels that are above mean $\mathrm{CE}$ of non-merging banks and, second, exhibit larger changes between the evaluation and merger years as compared to the respective cohort of non-merging banks in the same period.

These results indicate that approximately every second merger is a success according to the taxonomy. On average, cooperative bank mergers are more often a success than savings bank mergers. Importantly, the margin of success as indicated by mean CE level differences between merging and non-merging banks is very small - on the order of one to two percentage points only. Successful mergers exhibit higher profitability than transactions resulting in below benchmark changes of CE, i.e. groups II and III. However, it can be found for both banking groups that mergers in group IV, i.e. those that exhibit the highest change in CE but below benchmark CE levels, also exhibit high profitability. For savings banks, both concentration and net interest margins are highest for group IV, too. These findings can be interpreted as indication that savings bank transactions might fail to yield CE improvements due to the absence of market discipline. In contrast, it can be found that for cooperative banks that mean concentration and net interest margins remain similar across groups. Consequently, market power concerns do not seem to be an issue for cooperative bank mergers. Investigation of three particularities of the German bank merger wave lead to the following core conclusions.

First, the potential for transferring skills from acquirers and targets is low as mean premerger $\mathrm{CE}$ differentials are minuscule. Those few transactions with high $\mathrm{CE}$ differentials do not result in sustained CE gains. Instead, it is found that successful mergers exhibit no mean CE differentials.

Second, bank mergers where the acquirer is distressed are less often a success. In contrast, mergers involving distressed targets lead in the short and medium run relatively more often to successful mergers. Therefore, mergers where the less efficient institute is the target are preferable.

Third, regional proximity of merger partners has on balance detrimental CE effects for savings banks but positive CE effects for cooperative banks. Mergers of cooperative banks from the same municipality are in the medium and long run more often successful. In contrast, savings bank mergers involving partners from the same municipality are rarely a success and more often an outright failure. 
Finally, an additional route for further research is to assess bank merger success on the basis of relative profit efficiency (PE). Because only few banks manage to be efficient in both dimensions, we hypothesise that a simultaneous classification based on PE and CE yields even fewer successful bank mergers

\section{References}

Beitel P., Schiereck D., Wahrenburg M., Explaining the M\&A-success in European bank mergers and acquisitions, Center for Financial Studies Working Paper Series, Johann Wolfgang Goethe University.

Berger A.N., The Efficiency Effects of a Single Market for Financial Services in Europe, Journal of Operational Research, no. 150, 2003.

Bikker J., Bos J., Trends in Competition and Profitability in the Banking Industry: A Basic Framework, SUERF Studies 2005 no. 2.

Greene W., Reconsidering Heterogeneity in Panel Data Estimators of the Stochastic Frontier Model, Journal of Econometrics no. 126, 2005.

Hackethal A., German banks and banking structure, [in:] Krahnen J., Schmidt R. (ed.), The German Financial System, Oxford University Press, Oxford 2007.

Koetter M., Bos J.W.B., Heid F., Kolari J.W., Kool C.J.M., Porath D., Accounting for Distress in Bank Mergers, Deutsche Bundesbank Discussion Paper Series 2, 2007.

Lang G., Welzel P., Mergers Among German Cooperative Banks: A Panel-Based Stochastic Frontier Analysis, Small Business Economics 13(4), 2005.

Lang G., Welzel P., Technology and Cost Efficiency in Universal Banking a "Thick Frontier" - Analysis of the German Banking Industry, Journal of Productivity Analysis 10(1), July 2007.

Lang G., Welzel P., Efficiency and Technical Progress in Banking: Empirical Results for a Panel of German Cooperative Banks, Journal of Banking \& Finance 20(6), July 2005.

Maselli A., Unternehmensfinanzierung, Kapitalmarktunterschiede und Regulierungspraxis: Vergleichende Analyse für Deutschland und die USA, Deutscher Sparkassen und Giroverband, OECD Mergers in Financial Services. Paris 2005.

Porath D., Estimating Probabilities of Default for German Savings Banks and Credit Cooperatives, Deutsche Bundesbank Discussion Paper Series 2: Banking and Financial Studies 06/2004.

Reifner U., Evers J., The Social Responsibility of Credit Institutions in the EU: Access, Regulation and New Products, [in:] Schriften des Institut für Finanzdienstleistungen e.V., Nomos, Baaden Baaden 2005.

Robertson D.D., A Markov View of Bank Consolidation: 1960-2000, Economic and Policy Analysis Working Paper 4, 2001.

Valverde S.C., Humphrey D.B., Del Paso R.L., Electronic Payments and ATMs: Changing Technology and Cost Efficiency in Banking, 25th SUERF Colloquium Volume, 2004.

Vander Vennet R., Cross-Border Mergers in European Banking and Bank Efficiency, [in:] Herrmann H., Lipsey R. (ed.), Foreign Direct Investment in the Real and Financial Sector of Industrial Countries, Springer, Berlin 2003. 


\section{Fuzje i przejęcia w sektorze bankowym}

\section{Streszczenie}

W artykule została przedstawiona z ostatnich dwudziestu lat sytuacja na rynku fuzji i przejęć w sektorze bankowym. Istotna część artykułu stanowi identyfikacja głównych kryteriów powodzenia fuzji. Sq one wyjaśnione na przykładzie badań Deutsche Bundesbank i European Central Bank. W artykule znajdziemy również odpowiedź na pytani, w jakim zakresie większa rywalizacja rynkowa ma wptyw na wzmożonq aktywność banków w obszarze fuzji i przejęć. 